Article

\title{
An Integrative View of Emotion and the Dedication-Constraint Model in the Case of Coffee Chain Retailers
}

\author{
Daekil Kim ${ }^{1}$ and Byoungsoo Kim ${ }^{2, *}$ \\ 1 School of Communications and Media, Seoul Women's University, 621 Hwarangro, Nowon-Gu, \\ Seoul 01797, Korea; chris74@swu.ac.kr \\ 2 School of Business, Yeungnam University, 280 Daehakro, Gyeongsansi 38541, Korea \\ * Correspondence: kbsyu@yu.ac.kr; Tel.: +82-53-810-2730
}

Received: 22 October 2018; Accepted: 15 November 2018; Published: 19 November 2018

\begin{abstract}
Following the phenomenal growth of and competition among coffee chain retailers, the coffee chain market has expanded substantially thanks to rising income levels, the increasing young population, and rapidly changing lifestyles. Attracting consumers' attention and enhancing their loyalty behaviors has become very difficult for coffee chain retailers. This study seeks to understand the mechanisms through which emotions and the dedication-constraint model lead to brand loyalty and willingness to pay more to certain coffee chain retailers. Emotion responses and dedication-constraint model-based factors are major roles in the formation of loyalty behaviors, but few studies have combined them. To fill this knowledge gap, this study synthesizes emotional responses and the dedication-constraint model to develop a theoretical model. Based on the ambivalent view of emotions, it also examines how positive and negative emotions affect the combination of brand loyalty and willingness to pay more to certain coffee chain retailers. Moreover, it identifies the antecedents of affective and calculative commitments. Our findings indicate that affective commitment had significantly positive effects on positive emotion, brand loyalty, and willingness to pay more. It negatively affects negative emotion. Calculative commitment had significantly positive effects on positive emotion, brand loyalty, and willingness to pay more. However, contrary to our expectations, calculative commitment was positively related to negative emotions. Furthermore, service quality, quality of physical environment, and price fairness significantly affect affective commitments, while only price fairness significantly affects calculative commitments.
\end{abstract}

Keywords: emotion; commitment; brand loyalty; willingness to pay more; coffee quality; service quality; physical environment quality; price fairness

\section{Introduction}

Especially, the coffee industry not only provides high quality coffee, but also proposes a culture-oriented industry and, unlike the manufacturing industry, the coffee industry provides intangible assets such as emotions or human feelings. These have pushed coffee chain retailers to focus more on the perceived values like favorable feelings and emotions over their brands and thus develop a sustainability strategy to establish long-term relationships with consumers to inspire brand loyalty, form positive emotions, and induce customers to pay more. Improved consumer loyalty behaviors such as brand loyalty and willingness to pay more may lead to more revisits and higher consumption levels, resulting in larger revenues and higher profitability. Along with brand loyalty, willingness to pay more has been proven to be a key determinant of consumer loyalty behaviors in 
many studies [1-3]. Therefore, the importance of experienced satisfaction over service offerings has been well reported and studied in a way that inspires favorable feelings [4,5]. Most works on service management and marketing have focused on identifying the key factors of consumers' brand loyalty and willingness to pay more [6-8]. In highly competitive service markets such as the coffee chain industry, organizations strive to establish distinctive brand images that differentiate themselves from competitors with a view of forming favorable emotions toward their brands. A key to the construction and maintenance of healthy customer relationships is consumers' emotions $[7,8]$.

Previous studies have also indicated that consumers with positive emotions form stronger brand loyalty and willingness to pay more $[9,10]$. Several studies investigated the effects of emotions on consumer loyalty behaviors in the service industry [11,12]. According to the service-profit chain model, consumers with positive emotions develop brand loyalty and willingness to pay more, while consumers with negative emotions do not revisit the store and are thus not willing to pay more. Thus, emotions constitute a key determinant of consumers' post-purchase decisions in the service industry [11,12]. Another key mechanism for understanding consumer loyalty behaviors is dedication, which is a "psychological state that compels an individual toward a course of action" [13]. It consists of two main commitments: affective commitment and calculative commitment. Consumers' desire to maintain an enduring relationship with their current brand is part of the dedication-based mechanism, while the constraint-based mechanism focuses on maintaining current relationships and strengthening the lock-in effect $[14,15]$. Studies on the service industry have shown that brand loyalty and willingness to pay more both flow from dedication- and constraint-based mechanisms [16,17]. Zeithaml et al. [16] argued that willingness to pay more was a dimension of brand loyalty, influenced by both dedicationand constraint-based mechanisms through positive WOM (word of mouth) and complaint behaviors. Bloemer and Odekerken-Schröder [18] identified the vital roles played by psychological factors while examining the dedication-constraint model to identify the determinants of brand loyalty in the banking setting. Kaur and Soch [19] confirmed the salience of dedication- and constraint-based factors in the formation of customers' loyalty among Indian cellphone users. Jones et al. [20] also demonstrated the role of commitment and emotional mediators while emphasizing the behavioral outcomes in relation to the respondents' experience of the service provider or retailer. Affective and calculative commitments may stimulate both types of emotions simultaneously, establishing brand loyalty. This implies that both emotional responses and the dedication-constraint model affect loyalty behaviors.

A number of studies on service marketing investigated the effects of service experiences on consumers' repurchase decisions [21-23]. Customers tend to judge service experiences based on functional, mechanic, and humane cues [21,22]. The technical quality of the service is associated with functional cues such as drinking coffee at an appropriate temperature. Therefore, functional cues are essential for generating positive attitudes toward service experiences [23]. Physical environment factors (i.e., facility and atmosphere) may greatly influence customers' attitudes, service satisfaction, and behaviors [21,22]. The ambience at a coffee chain outlet provides distinctive stimuli to customers through the interiors and layout, so that the customers may develop positive attitudes toward the outlet. Service performance factors such as the employees' tone of voice and empathy are associated with humane cues. For coffee chain consumers, friendly smiles and sincere greetings from employees can create superior customer experiences [23,24]. However, very few studies have examined these three aspects of the service experience in relation to consumer satisfaction with, and brand images of, coffee chains. From the viewpoint of the dedication-based mechanism, this study assumes that coffee quality, physical environment quality, and service quality are service experience components that are vital for developing affective commitment and calculative commitment. These aspects have hardly been studied in relation to loyalty behaviors, such as brand loyalty, or willingness to pay more to coffee chains.

In summary, this study's research model explains how different types of commitments differentially affect positive and negative emotions in the context of coffee chain retailers. A review of 
studies on commitment indicates that the linkages between affective and calculative commitments and coffee quality, service quality, physical environment quality, and price fairness should also be analyzed.

The remainder of this paper is organized as follows. The next section presents the theoretical background for the research model. Section 3 describes the study's theoretical model and hypotheses. Section 4 reports the research methodology and the characteristics of the study's respondents. Section 5 presents the analysis results, while Section 6 discusses the findings, provides several implications for researchers and practitioners, and outlines the limitations of the study.

\section{Theoretical Background and Research Model}

\subsection{Emotions}

Certain user experiences generate emotions, referred to as "affective responses" [25]. Several studies indicated that responses induce emotions through the use of a product or service $[25,26]$. Consumers use emotional responses elicited by purchase experiences as a basis for evaluating services or products. Emotions are distinct from moods, which are transient and changeable [27,28]. Emotions are relatively steady and enduring, while moods are less intense and situation-specific [29,30]. Some studies indicated that emotions affect consumers' loyalty behaviors. Several studies on service management and marketing have shown that consumption emotions significantly affect consumers' loyalty behaviors. Jones et al. [20] investigated the effects of consumers' emotions on their repurchase intentions and negative WOM. They found that both affective and calculative commitments were main sources of the drivers of consumers' emotions. Lee et al. [31] examined the links among festival scales, patron emotions, and loyalty in an international festival context. They found that consumers' judgments about festival environments drove their emotions, thereby affecting subsequent behavioral intentions. Jung and Yoon [32] investigated the links between employees' nonverbal communication, consumers' emotions, and satisfaction in the family restaurant setting. Emotional responses in the service industry stem mainly from interactions with employees or evaluations of store facilities. However, pleasure or emotional usage experiences about IS services can also trigger emotional responses. Beaudry and Pinsonneault [33] showed that positive emotions such as excitement and happiness significantly affected users' adoption behaviors. Wakefield [34] assumed that users' intentions to disclose personal information in the context of websites related to negative emotions.

Several studies on consumer behaviors and marketing demonstrated that emotions consist of two dominant dimensions, positive and negative, that are orthogonal to each other [35,36]. Happiness, love, and pride are associated with positive emotions, while fear, anger, and sadness relate to negative emotions [35]. The independent and distinct factors that affect consumers' purchase-related decision-making have been identified with positive and negative emotions $[37,38]$. Positive emotions may promote repurchase intentions and positive WOM, while negative emotions may lead to negative WOM and discontinuance intentions. Several studies have shown that positive emotions experienced by customers affect revisit intentions more significantly than negative emotions do. For instance, Phillips and Baumgartner [36] demonstrated that positive emotions are a stronger determinant of consumer satisfaction than negative emotions were. Pappas, Kourouthanassis, and Giannakos [39] also noted the role of positive emotions (vs. negative emotions) in influencing customer purchase intentions for personalized services. On the other hand, other studies have indicated that negative emotions have stronger effects on outcomes because customers typically weigh losses more heavily than gains [20]. Kuo and $\mathrm{Wu}$ [40] found a stronger relationship between negative emotion and satisfaction than between positive emotions and satisfaction in service recovery situations. Jones et al. [20] showed that negative emotion had a greater effect on post-purchase behaviors, such as repurchase intentions and the spread of WOM, than positive emotions had. In fact, they found that positive emotions had no influence on repurchase intentions or the spread of WOM. Therefore, a simultaneous examination of consumers' positive and negative emotions is essential for understanding the differential roles of these 
two components in consumer loyalty. We thus assume that two major components of emotion are the core components of consumer loyalty behaviors in the context of coffee chains.

\subsection{Dedication-Constraint Model}

Researchers on service management have increasingly recognized the importance of commitment in explaining brand loyalty in diverse service environments [20,41]. Commitment is defined as a "psychological state that compels an individual toward a course of action" [13]. Several works have suggested that emotions result from affective commitment and calculative commitment [23]. The dedication-constraint model concerns these two distinctive commitments [14,15]. A number of studies have concentrated on affective commitment as a dedication factor. Affective commitment may explain brand loyalty and may encourage customers to pay more. Loyal consumers not only continually revisit their preferred brand but are also willing to pay higher prices for it. Several studies on marketing and service management indicated that dedication- and constraint-based mechanisms can provide an in-depth understanding of why customers' relationships with their current service providers are maintained and retained [42,43]. Customers establish relationships with their service providers either because they want to receive the benefits based on favorable experiences or have few other choices. Zhou et al. [42] developed a dedication- and constraint-based framework by integrating the affective and calculative commitments in the context of the social virtual world. They also identified the key antecedents of dedication and constraint factors. Lin et al. [43] studied the telecommunication industry using the dedication/constraint model and employing customer loyalty as a variable. They proved that constraint-based factors were associated with customer loyalty more strongly than dedication-based factors were. Baloglu et al. [44] applied the dedication-constraint model to examine consumer loyalty in the casino context.

According to the social exchange theory, dedication reflects an emotion-based evaluation that leads to maintaining a long-term relationship with the current service provider [14]. Gounaris [45] examined the concept of "affective commitment", a positive perception of and attachment to a certain service provider, constructed on dedication-based mechanisms. An affectively committed service provider maintains a long-term relationship by providing consumers with favorable experiences that fulfill their psychological needs. Constraint-based mechanisms are used to capture consumers through calculative commitment, which reflects consumers' cognition, reduces interest in alternative services, and creates a lock-in effect [46]. Lu et al. [47] investigated the role played by service value and switching barriers in customer loyalty behaviors in the passenger transportation service context. Kim [48] demonstrated that emotions- and dedication-constraint-based factors jointly formed consumer loyalty to a mobile messenger service. These results indicated that both dedication- and constraint-based mechanisms explained the variance in consumer loyalty. Most studies have indicated that dedication-based factors in the coffee chain context, such as consumer satisfaction and brand image, were dominant but that some consumers tend to retain relationships with a certain coffee chain because of brand loyalty, to avoid incurring losses in economic, social, or psychological investments by switching to another coffee chain. Therefore, this study suggests that a dual model would provide comprehensive information on customer's loyalty behaviors.

The desire to make and maintain long-term relationships relates to dedication-based mechanisms, while forces that constrain consumers to current relationships regardless of the perceived benefits (such as coffee quality, service quality, physical environment quality, and price fairness) are associated with constraint-based mechanisms. In the coffee chain retailer environment, since both dedication and constraint factors may affect brand loyalty and willingness to pay more, the dedication-constraint model is suitable for explaining consumer loyalty behaviors. Therefore, we develop a theoretical model based on the integrated view of emotion response and dedication-constraint model. 


\section{Research Model and Hypotheses}

Consumer loyalty has been predicted based on two main research streams: emotions and the dedication-constraint model. Placing model development in the context of coffee chain retailers, we also propose that coffee quality, service quality, physical environment quality, and price fairness are four drivers of affective and calculative commitment to the two key loyalty behaviors: brand loyalty and willingness to pay more. The research model is illustrated in Figure 1.

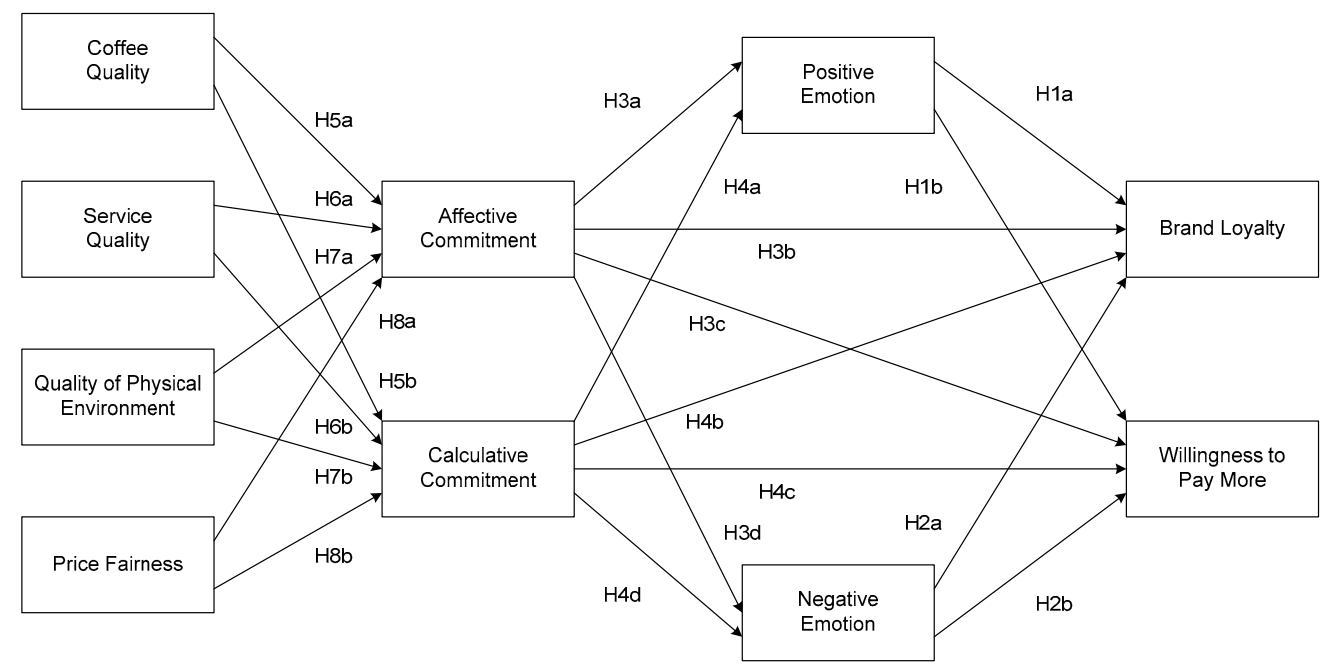

Figure 1. Research model.

\subsection{Emotions}

Customer loyalty consists of loyalty behaviors (customers' repeated purchase of current brands rather than competitor brands) and encompasses loyal attitudes, opinions, and feelings about products. Firms seek to create brand loyalty because retaining existing customers is less costly than obtaining new ones. Tanford et al. [49] showed that loyalty behaviors, such as the willingness to pay more for a hotel room, related positively to emotional commitment. Positive emotions such as delight and elation [50] were found to arise from the cognitive process of confirmation/disconfirmation and contribute to (dis)satisfaction. Jones et al. [20] examined the differential roles of negative and positive emotions in the formation of repurchase intentions and the spread of negative WOM. Yu and Dean [12] found significant relationships between emotional components and customer loyalty behaviors. Chea and Luo [51] found that negative emotions significantly influences complaints, while positive emotions had no significant effect on user satisfaction and recommendation intention. Jung and Yoon [32] examined the impacts of consumers' positive and negative emotions on customer satisfaction in the family restaurant setting. In particular, they found that willingness to pay more was positively associated with positive emotions. Willingness-to-pay more is defined as "the willingness to accept higher prices than a competitor's and continue to use a preferred brand even if it raises its prices" [52]. Tanford et al. [49] found that willingness to pay more was the premium customers paid for a brand to which they were loyal. Strahilevitz [53] noted that emotions affected consumers' willingness to pay more for a charity-linked brand.

In the context of coffee chain retailers, the emotions consumers feel while using services comprise core components of their loyalty behaviors [54]. In particular, positive and negative emotions tend to increase and decrease brand loyalty and willingness to pay more, respectively. We examine the relative effects of each type of consumer emotion on brand loyalty and willingness to pay more. Using a higher feeling of trust as an indicator of customer loyalty, Delgado-Ballester and Munuera-Aleman [55] found an empirical evidence that customer loyalty affected the level of price tolerance. It is thus reasonable to conclude that emotions led to customers' brand loyalty and willingness to pay more, thereby indirectly affecting the outcomes of loyalty behaviors. We thus propose the following. 
Hypothesis 1a (H1a). Positive emotions have a positive effect on brand loyalty.

Hypothesis $\mathbf{1 b}(\mathbf{H 1} \mathbf{b})$. Positive emotions have a positive effect on willingness to pay more.

Hypothesis 2a (H2a). Negative emotions have a negative effect on brand loyalty.

Hypothesis $\mathbf{2 b}(\mathbf{H} \mathbf{2} \mathbf{b})$. Negative emotions have a negative effect on willingness to pay more.

\subsection{Commitment}

Affective commitment is an enduring desire to attract consumers and maintain relationships with service providers. Affective commitment pertains to psychological attachment caused by positive sentiment and identification. Verhoef [56] showed that affective commitment had significant effects on relationship maintenance in the context of financial services. Some researchers have found that affective commitment reflected customers' involvement in a long-term relationship due to a fun and delight experience $[48,56]$. Customers with a high level of affective commitment are likely to stay with the current service provider and avoid engaging in any activities that are detrimental to it. Therefore, many service providers try to enhance customers' affective commitment to them because customers with a high level of affective commitment become more loyal, even when prices are raised, which means that they become more willing to pay more for their service. Several studies have posited that affective commitment is a main element of dedication-based mechanisms [57]. Favorable and delightful experiences that fulfill a consumer's needs facilitate the development of affective commitment, which, in turn, builds brand loyalty. In the context of coffee chain retailers, affective commitment plays a vital role in forming loyalty behaviors. Much empirical research in marketing has shown that affective commitment evokes positive emotional responses and alleviates negative emotional outcomes [20]. Han et al. [58] proposed a theoretical framework for brand loyalty and provided sufficient explanatory power when investigating affective and cognition commitments in the context of the coffee shop chain industry. The two main types of commitments are affective and continuance [59]. Affective commitment is the aspiration to cultivate a long-term relationship led by loyalty [60], while constraint commitment typically stems from consumers' rational motives related to switching costs [59].

Coffee chain customers with a high level of affective commitment want to stay with the current service provider due to positive benefits and the sense of belonging. Therefore, such customers' psychological attachment to the coffee chain service provider generates positive emotions and mitigates negative emotions. A number of researchers have suggested the positive links between affective commitment and brand loyalty [61,62], finding positive effects of affective commitment on brand loyalty. Consumers with an emotional attachment to a certain coffee chain tend to express their loyalty behaviorally and vigorously by revisiting, spreading positive WOM, and not visiting competitors' stores. Thus, the following hypotheses are proposed.

Hypothesis 3a (H3a). Affective commitment positively influences positive emotions.

Hypothesis $3 \mathbf{b} \mathbf{( H 3 b ) . ~ A f f e c t i v e ~ c o m m i t m e n t ~ p o s i t i v e l y ~ i n f l u e n c e s ~ b r a n d ~ r o y a l t y . ~}$

Hypothesis 3c (H3c). Affective commitment positively influences willingness to pay more.

Hypothesis 3d (H3d). Affective commitment positively influences negative emotions.

Calculative commitment is the degree to which consumers recognize that existing service provider locks them in due to the potential costs of switching to alternative service provider or discontinuance [63]. Calculative commitment induces consumers to maintain a long-term relationship because of the relatively high costs associated with switching or discontinuance [64]. Bilgihan and 
Bujisic [65] examined the positive effect of calculative commitment in building up brand loyalty to hotel booking sites. They reported that consumers who perceived high switching costs and a lack of alternatives were likely to stay with their current service provider.

In the context of coffee chain retailers, Yang et al. [66] found that consumer commitments, including calculative commitment, positively affected brand loyalty and the repeated use of current franchises and chain coffee shops. They discovered that consumers with close relationships with service providers repeatedly used their current chain coffee shops because of the strong enforcement of customer commitment. Therefore, calculative commitment is likely to build brand loyalty since consumers with high levels of calculative commitment have a strong lock-in commitment. However, other researchers have suggested that calculative commitment acts as a negative motivation against continuing a current relationship [20]. Calculative commitment can induce consumers to perceive the current relationship negatively due to their perceived loss of control. According to the self-determination theory, perceptions of a reduced freedom of choice or self-determination tend to lead to negative reactions [67]. In line with the self-determination theory, Jones et al. [20] demonstrated the positive effects of calculative commitment on negative emotions. In the context of coffee chain retailers, calculative commitment may be regarded as a negative motivation that evokes negative emotions when service providers have locked in consumers due to the reduction of alternatives and the huge investments made. We thus propose the following:

Hypothesis 4a (H4a). Calculative commitment positively influences positive emotions.

Hypothesis $\mathbf{4 b}(\mathbf{H} 4 \mathbf{b})$. Calculative commitment positively influences brand royalty.

Hypothesis 4c (H4c). Calculative commitment positively influences willingness to pay more.

Hypothesis $4 \mathbf{d}(\mathbf{H} 4 \mathbf{d})$. Calculative commitment positively influences negative emotions.

\subsection{Coffee Quality}

Coffee quality arises through the evaluation of coffee served by coffee chains [24]. It is a functional cue of service experiences and a fundamental attribute of coffee chains. Freshness, aroma, flavor, and temperature all affect coffee quality [24,66]. Consumers' perceptions of coffee quality affect their decisions to patronize a coffee chain and make revisit decisions. Kim et al. [4] noted that bean quality, flavor, and aroma are key factors in evaluations of coffee chains. A positive evaluation of coffee aroma, freshness, and temperature may improve consumer satisfaction with a coffee chain [23]. Furthermore, consumers' assessment of the superiority and excellence of coffee quality may affect affective and calculative commitments in the coffee chain. Yang et al. [66] provided empirical evidence that customer commitments, including affective and calculative commitments, were positively associated with coffee quality. Excellent consumer experiences with a flavorful coffee should reinforce both affective and calculative commitments in the coffee chain. We thus propose the following:

Hypothesis 5a (H5a). Coffee quality positively influences affective commitment.

Hypothesis $5 \mathbf{b}(\mathbf{H} 5 b)$. Coffee quality positively influences calculative commitment.

Service quality is the evaluation of the services provided by employees and service workers [16]. Service quality can provide a consumer's subjective responses about coffee chains based on employees' attitudes and performance during service offer $[4,16]$. Excellent service by courteous employees brings higher customer satisfaction. Several studies verified a significant role of service quality for customers' delightful experience as well as brand loyalty in restaurants, hotels, and bakeries. Ryu et al. [68] indicated that intangible service qualities, such as helpful employees, individualized customer attention, and efficient customer service, played a significant role in developing consumers' positive service experience. Coffee 
customers grade the quality service based on service provider's attitude, empathy and performance [16,24]. Therefore, service quality is a critical factor of both affective and calculative commitments.

Hypothesis 6a (H6a). Service quality positively influences affective commitment.

Hypothesis $\mathbf{6 b}(\mathbf{H 6 b})$. Service quality positively influences calculative commitment.

The quality of physical environment arises through customers' emotional responses to the physical surroundings [69]. Mechanical clues are a critical factor in service management because the intangibility of the services they receive forces customers to rely on tangible evidence when assessing their service experiences [68]. Han and Ryu [70] indicated that customers' perceptions of the servicescape such as artifacts, spatial layout, and ambient conditions strengthened their positive experiences at restaurants. Furthermore, several studies demonstrated that the physical environments in hotels and restaurants strengthened brand loyalty [70]. Tumanan and Lansangan [71] showed that physical elements such as design and layout played a prominent role in developing positive customer experiences in coffee chains. Alan et al. [23] found that the psychical atmospheric environment was a primary component of store-related cognitions that would evoke positive emotions and customer satisfaction. Yang et al. [66] concluded that an effective strategy for enhancing the customer experience was to improve the quality of the atmosphere (facilities and ambient/lighting) with a view to enhancing affective and calculative commitments. Therefore, consumers' awareness of the physical surroundings during a stay of a coffee shop and their evaluation are likely to play key roles in affective and calculative commitments. We thus propose the following:

Hypothesis 7a (H7a). Physical environment quality positively influences affective commitment.

Hypothesis $\mathbf{7 b} \mathbf{( H 7 b ) . ~ P h y s i c a l ~ e n v i r o n m e n t ~ q u a l i t y ~ p o s i t i v e l y ~ i n f l u e n c e s ~ c a l c u l a t i v e ~ c o m m i t m e n t . ~}$

\subsection{Price Fairness}

Price fairness arises from subjective perceptions about prices. Unlike an objective price, which are determined by the monetary cost of a product/service [72] and becomes acceptable to customers only when the impute price impression is valid to them, a perceived subjective price means the impute price impression formed when customers individually assess prices based on product/service quality information [73,74]. Price fairness is achieved when customers perceive the price of a particular offer as "being right, just, or legitimate instead of being wrong, unjust, or illegitimate" [75,76]. Price fairness reflects the fairness of a particular outcome. The process of bringing about the outcome relates to procedural price fairness. Perceived prices are considered as a reliable indicator of product/service quality. Customer perceptions of price fairness were found to enhance the quality of the relationship between luxury restaurants and customers, leading to customer loyalty [70]. Customers who regard a price as absurd to the extent that they feel cheated become dissatisfied and fail to establish long-term relationships with the current service provider [77]. Yang et al. [66] utilized prices fairness as an indicator of the performance of customer experiences in the context of coffee chain retailers. Given the above, we propose the following.

Hypothesis 8a (H8a). Price fairness positively influences affective commitment.

Hypothesis $\mathbf{8 b} \mathbf{( H 8 b ) . ~ P r i c e ~ f a i r n e s s ~ p o s i t i v e l y ~ i n f l u e n c e s ~ c a l c u l a t i v e ~ c o m m i t m e n t . ~}$

\section{Research Methodology}

\subsection{Instrument Development}

We selected survey items from validated studies and modified to suit the coffee chain context. The questionnaire consist of two sections. The first included questions that measured the constructs 
in the research model. This scale employed a seven-point Likert-type scale from strongly disagree to strongly agree. The second section, the demographic information gathered age, gender, and monthly average consumption expenses. Before the main survey was conducted, scholars in the field of specialization reviewed the questionnaire to check for problems with content, wording, and question ambiguity. The modified questionnaire was pilot-tested on 50 university students. All constructs in the theoretical framework were verified for reliability based on Cronbach's alpha values; all exceed the accepted 0.7 level of reliability. Appendix A lists the survey items of the model constructs.

\subsection{Data Collection}

We gathered empirical data from a leading online research company using a wide range of panels in South Korea. A link for the survey was e-mailed to roughly 1000 panels and advertised on the website of the research company from 21-30 September 2017. This method is a useful way to overcome sample bias and obtain generalizable analysis results. After frivolous and insincere responses were deleted through data filtering, 400 responses remained for the analysis. Of the final sample, $51.2 \%$ of respondents were female. The ages of respondents ranged from 20 to 65, with a mean age of 39.33 and a standard deviation of 10.022. Table 1 provides demographic information on the respondents.

Table 1. Profile of respondents.

\begin{tabular}{|c|c|c|c|}
\hline \multirow{2}{*}{ Demographics } & \multirow{2}{*}{ Item } & \multicolumn{2}{|c|}{ Subjects } \\
\hline & & Frequency & Percentage \\
\hline \multirow{2}{*}{ Gender } & Male & 195 & 48.8 \\
\hline & Female & 205 & 51.2 \\
\hline \multirow{4}{*}{ Age } & Less than 30 & 75 & 18.8 \\
\hline & 30-39 & 139 & 34.8 \\
\hline & $40-49$ & 122 & 30.5 \\
\hline & More than 50 & 64 & 16.0 \\
\hline \multirow{6}{*}{$\begin{array}{l}\text { Average Income per } \\
\text { month }\end{array}$} & Less than 500,000 won & 36 & 9.0 \\
\hline & $500,000-1,000,000$ won & 27 & 6.8 \\
\hline & $1,000,000-2,000,000$ won & 73 & 18.3 \\
\hline & $2,000,000-3,000,000$ won & 86 & 21.5 \\
\hline & $3,000,000-5,000,000$ won & 120 & 30.0 \\
\hline & More than $5,000,000$ won & 58 & 14.5 \\
\hline \multirow{5}{*}{$\begin{array}{l}\text { Visiting frequency at } \\
\text { coffee chain per month }\end{array}$} & Once & 34 & 8.6 \\
\hline & $2-5$ times & 189 & 47.3 \\
\hline & 6-10 times & 88 & 22.0 \\
\hline & 11-20 times & 66 & 16.5 \\
\hline & More than 20 times & 23 & 5.8 \\
\hline \multirow{7}{*}{$\begin{array}{l}\text { Average expenditure at } \\
\text { coffee chain per month }\end{array}$} & Less than 5000 won & 14 & 3.5 \\
\hline & 5000-10,000 won & 50 & 12.5 \\
\hline & $10,000-20,000$ won & 71 & 17.8 \\
\hline & $20,000-30,000$ won & 75 & 18.8 \\
\hline & $30,000-50,000$ won & 99 & 24.8 \\
\hline & $50,000-100,000$ won & 64 & 16.0 \\
\hline & More than 100,000 won & 27 & 6.8 \\
\hline
\end{tabular}

Note: $1 \$ \approx 1200$ won.

\subsection{Data Analysis}

We analyzed the theoretical framework using the partial least squares (PLS) method with SmartPLS. The PLS is well suited for research using complex predictive models [78]. Moreover, this method places fewer restrictions on sample size and residual distributions than covariance-based structural equation models such as LISREL and AMOS [78]. The PLS method has been found to be useful in the marketing, service management, and hospitality management domains. A two-step approach suggested by Anderson and Gerbing [79] was used to assess the measurement model and structural model for reliability, convergent validity, and discriminant validity. 


\section{Results}

\subsection{Measurement Model}

Reliability, convergent validity, and discriminant validity were assessed through confirmatory factor analysis. First, in verifying the reliability of the constructs, composite reliability (CR), average variance extracted (AVE), and Cronbach's alpha are acceptable if the CR and Cronbach's alpha values exceed 0.70 and if the AVE values exceed 0.50 [80]. As shown in Table 2, all factors in the theoretical model have acceptable values. Second, to check convergent validity, this study examined the factor loading values of the measurement items, as shown in Table 2. Convergent validity is acceptable if the factor loading values exceed 0.70 [81]. The lowest factor loading in this study was 0.703 (SEQ1), which confirmed convergent validity. Finally, the AVE values of the individual factors were compared to the shared variances between them to investigate discriminant validity. In Table 3, the diagonal elements are the values of the square root of the AVE. All the AVE values is higher than those of the off-diagonal elements in the corresponding columns and rows, satisfying discriminant validity.

Table 2. Scale reliabilities.

\begin{tabular}{|c|c|c|c|c|c|c|c|}
\hline Construct & Item & Mean & St. dev. & Factor Loading & Cronbach's Alpha & CR & AVE \\
\hline \multirow{4}{*}{ Brand loyalty } & BRL1 & 4.782 & 1.275 & 0.832 & \multirow{4}{*}{0.882} & \multirow{4}{*}{0.919} & \multirow{4}{*}{0.739} \\
\hline & BRL2 & 4.400 & 1.533 & 0.864 & & & \\
\hline & BRL3 & 4.785 & 1.278 & 0.869 & & & \\
\hline & BRL4 & 4.665 & 1.301 & 0.873 & & & \\
\hline \multirow{3}{*}{ Willingness to pay more } & WPM1 & 4.537 & 1.372 & 0.885 & \multirow{3}{*}{0.858} & \multirow{3}{*}{0.913} & \multirow{3}{*}{0.779} \\
\hline & WPM2 & 4.530 & 1.405 & 0.887 & & & \\
\hline & WPM3 & 4.522 & 1.554 & 0.875 & & & \\
\hline \multirow{3}{*}{ Positive emotion } & PEM1 & 4.673 & 1.156 & 0.866 & \multirow{3}{*}{0.762} & \multirow{3}{*}{0.863} & \multirow{3}{*}{0.678} \\
\hline & PEM2 & 4.270 & 1.354 & 0.805 & & & \\
\hline & PEM3 & 4.888 & 1.122 & 0.798 & & & \\
\hline \multirow{3}{*}{ Negative emotion } & NEM1 & 2.792 & 1.189 & 0.925 & \multirow{3}{*}{0.927} & \multirow{3}{*}{0.953} & \multirow{3}{*}{0.872} \\
\hline & NEM2 & 2.533 & 1.187 & 0.932 & & & \\
\hline & NEM3 & 2.587 & 1.293 & 0.944 & & & \\
\hline \multirow{3}{*}{ Affective commitment } & ACO1 & 5.263 & 1.117 & 0.860 & \multirow{3}{*}{0.844} & \multirow{3}{*}{0.906} & \multirow{3}{*}{0.762} \\
\hline & $\mathrm{ACO} 2$ & 4.985 & 1.212 & 0.890 & & & \\
\hline & $\mathrm{ACO} 3$ & 4.758 & 1.322 & 0.868 & & & \\
\hline \multirow{4}{*}{ Calculative commitment } & CCO1 & 4.470 & 1.421 & 0.868 & \multirow{4}{*}{0.902} & \multirow{4}{*}{0.931} & \multirow{4}{*}{0.772} \\
\hline & $\mathrm{CCO} 2$ & 4.327 & 1.518 & 0.863 & & & \\
\hline & $\mathrm{CCO} 3$ & 4.008 & 1.639 & 0.900 & & & \\
\hline & $\mathrm{CCO} 4$ & 3.825 & 1.716 & 0.883 & & & \\
\hline \multirow{4}{*}{ Coffe equality } & COQ1 & 5.200 & 1.127 & 0.856 & \multirow{4}{*}{0.868} & \multirow{4}{*}{0.91} & \\
\hline & COQ2 & 5.200 & 1.114 & 0.883 & & & 0.716 \\
\hline & COQ3 & 5.295 & 1.157 & 0.844 & & & \\
\hline & COQ4 & 5.315 & 1.098 & 0.800 & & & \\
\hline & SEQ1 & 5.543 & 1.155 & 0.703 & & & \\
\hline Servic equality & SEQ2 & 5.415 & 1.071 & 0.807 & 0.825 & 0881 & 0.651 \\
\hline & SEQ3 & 5.190 & 1.135 & 0.845 & & & \\
\hline & SEQ4 & 5.258 & 1.107 & 0.863 & & & \\
\hline & QPE1 & 5.237 & 1.061 & 0.827 & & & \\
\hline Quality of physical & QPE2 & 5.370 & 1.053 & 0.833 & 0.838 & 0.892 & 0.673 \\
\hline environment & QPE3 & 5.338 & 1.039 & 0.811 & & & \\
\hline & QPE4 & 5.405 & 1.042 & 0.811 & & & \\
\hline & PFA1 & 4.280 & 1.434 & 0.912 & & & \\
\hline Price fairness & PFA2 & 4.255 & 1.493 & 0.926 & 0.944 & 0.96 & 0.856 \\
\hline Hitce lanitiess & PFA3 & 4.308 & 1.455 & 0.933 & & & \\
\hline & PFA4 & 4.207 & 1.510 & 0.930 & & & \\
\hline
\end{tabular}


Table 3. Correlation matrix and discriminant assessment.

\begin{tabular}{|c|c|c|c|c|c|c|c|c|c|c|}
\hline & 1 & 2 & 3 & 4 & 5 & 6 & 7 & 8 & 9 & 10 \\
\hline 1. Brand loyalty & 0.860 & & & & & & & & & \\
\hline 2. Willingness to pay more & 0.743 & 0.882 & & & & & & & & \\
\hline 3. Positive emotion & 0.681 & 0.636 & 0.824 & & & & & & & \\
\hline 4. Negative emotion & -0.226 & -0.201 & -0.251 & 0.934 & & & & & & \\
\hline 5. Affective commitment & 0.662 & 0.633 & 0.610 & -0.299 & 0.873 & & & & & \\
\hline 6. Calculative commitment & 0.651 & 0.601 & 0.533 & 0.076 & 0.497 & 0.879 & & & & \\
\hline 7. Coffee quality & 0.458 & 0.432 & 0.500 & -0.301 & 0.491 & 0.226 & 0.846 & & & \\
\hline 8. Service quality & 0.407 & 0.388 & 0.443 & -0.372 & 0.571 & 0.272 & 0.586 & 0.807 & & \\
\hline 9. Quality of physical environment & 0.396 & 0.369 & 0.402 & -0.335 & 0.569 & 0.189 & 0.626 & 0.727 & 0.821 & \\
\hline 10. Price fairness & 0.501 & 0.511 & 0.435 & -0.154 & 0.467 & 0.530 & 0.284 & 0.332 & 0.239 & 0.925 \\
\hline
\end{tabular}

\subsection{Structural Model}

This study tested the theoretical framework using a bootstrap resampling procedure with 500 resamples. Figure 2 presents the analysis results.

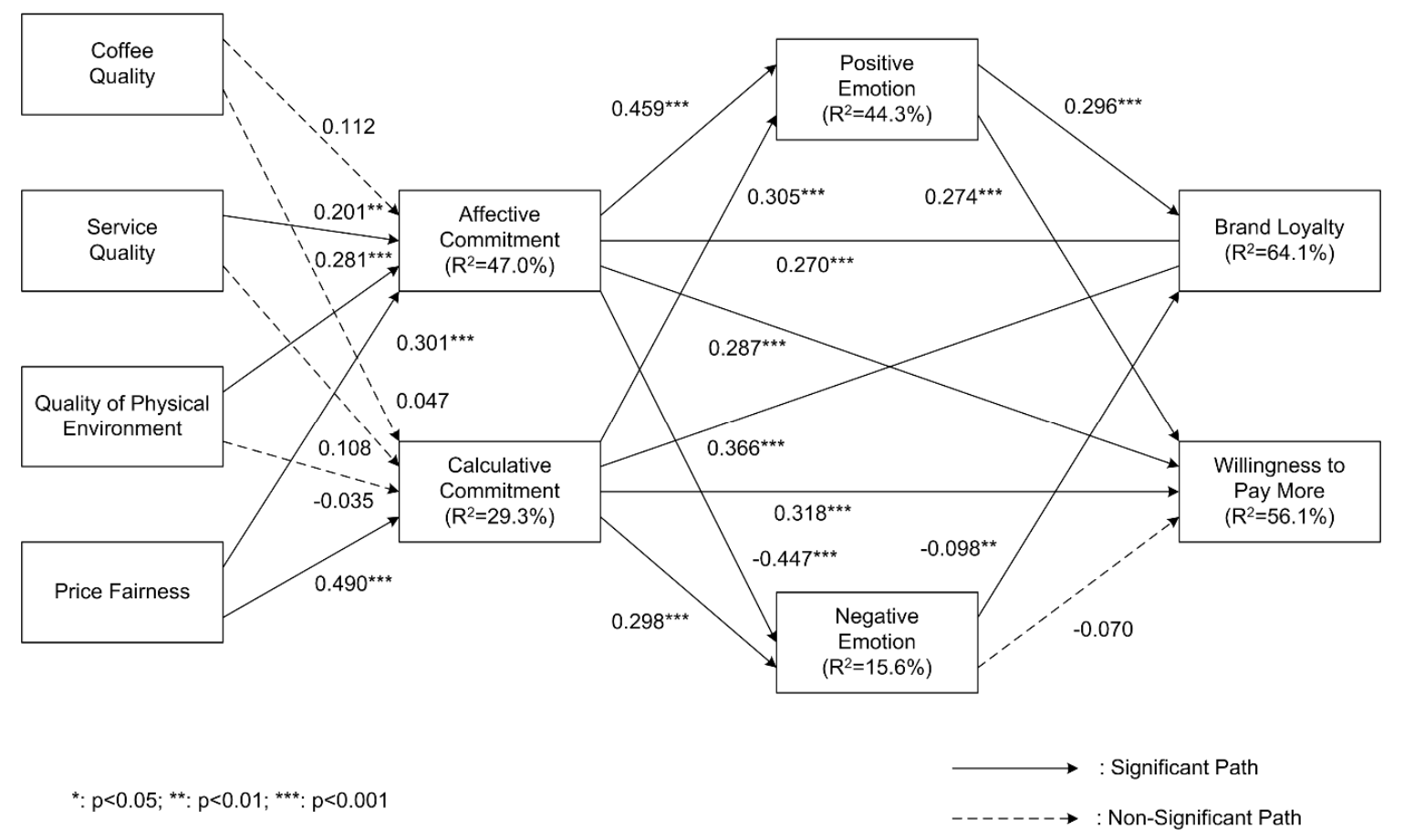

Figure 2. The analysis results.

Our theoretical framework accounted for $64.1 \%$ of the variance of brand loyalty. The theoretical framework also accounted for $56.1 \%$ of the variance of willingness to pay more. Positive emotion had significantly positive effects on brand loyalty and willingness to pay more, while negative emotion had a negative effect on brand loyalty, thereby providing empirical support for H1a, H1b, and $\mathrm{H} 2 \mathrm{a}$, respectively. However, negative emotion had no significant effect on willingness to pay more, rejecting $\mathrm{H} 2 \mathrm{~b}$. Consistent with our expectations, affective commitment had significantly positive effects on positive emotion, brand loyalty, willingness to pay more. It negatively influences negative emotion, supporting $\mathrm{H} 3 \mathrm{a}, \mathrm{H} 3 \mathrm{~b}, \mathrm{H} 3 \mathrm{c}$, and $\mathrm{H} 3 \mathrm{~d}$. Calculative commitment had significantly positive effects on positive emotion, brand loyalty, and willingness to pay more. However, contrary to our expectations, calculative commitment was positively related to negative emotions. These results supported $\mathrm{H} 4 \mathrm{a}$, $\mathrm{H} 4 \mathrm{~b}$, and $\mathrm{H} 4 \mathrm{c}$ but rejected $\mathrm{H} 4 \mathrm{~d}$. The antecedents of positive and negative emotion explained $44.3 \%$ of the former variance and $15.6 \%$ of the latter variance. Service quality, physical environment quality, 
and price fairness had significant effects on affective commitment, supporting H6a, H7a, and H8a. However, coffee quality had no significant effect on affective commitment, rejecting H5a. Price fairness was significantly associated with calculative commitment, supporting H8b. However, contrary to our expectations, coffee quality, service quality, and quality of physical environment were not significantly associated with calculative commitment. Therefore, $\mathrm{H} 5 \mathrm{~b}, \mathrm{H} 6 \mathrm{~b}$, and $\mathrm{H} 7 \mathrm{~b}$ were not supported, while $\mathrm{H} 8 \mathrm{~b}$ was supported. These determinants explained $47.0 \%$ of the variance of affective commitment and $29.3 \%$ of the variance of calculative commitment. Table 4 summarizes the study's results.

Table 4. Summary of the results.

\begin{tabular}{lccccc}
\hline & Cause & Effect & Coefficient & $t$-Value & Hypothesis \\
\hline H1a & Positive emotion & Brand loyalty & 0.296 & 4.863 & Supported \\
H1b & Positive emotion & Willingness to pay more & 0.274 & 4.583 & Supported \\
H2a & Negative emotion & Brand loyalty & -0.098 & 2.644 & Supported \\
H2b & Negative emotion & Willingness to pay more & -0.07 & 1.543 & Not Supported \\
H3a & Affective commitment & Positive emotion & 0.459 & 9.030 & Supported \\
H3b & Affective commitment & Brand loyalty & 0.270 & 4.412 & Supported \\
H3c & Affective commitment & Willingness to pay more & 0.287 & 4.351 & Supported \\
H3d & Affective commitment & Negative emotion & -0.447 & 7.908 & Supported \\
H4a & Calculative commitment & Positive emotion & 0.305 & 6.151 & Supported \\
H4b & Calculative commitment & Brand loyalty & 0.366 & 7.753 & Supported \\
H4c & Calculative commitment & Willingness to pay more & 0.318 & 5.784 & Supported \\
H4d & Calculative commitment & Negative emotion & 0.298 & 5.629 & Supported \\
H5a & Affective commitment & Coffee quality & 0.112 & 1.460 & Not Supported \\
H6a & Affective commitment & Service quality & 0.201 & 2.784 & Supported \\
H7a & Affective commitment & Quality of physical environment & 0.281 & 3.819 & Supported \\
H8a & Affective commitment & Price fairness & 0.301 & 6.569 & Supported \\
H5b & Calculative commitment & Coffee quality & 0.047 & 0.801 & Not Supported \\
H6b & Calculative commitment & Service quality & 0.108 & 1.378 & Not Supported \\
H7b & Calculative commitment & Quality of physical environment & -0.035 & 0.482 & Not Supported \\
H8b & Calculative commitment & Price fairness & 0.490 & 9.872 & Supported \\
\hline
\end{tabular}

\section{Implications}

\subsection{Summary of Results}

Our proposed model provides strong explanatory power concerning brand loyalty and willingness to pay more, accounting for more than $50.0 \%$ of these variances. Our findings also indicate that dedication- and constraint-based factors play a vital role in developing brand loyalty and willingness to pay more. Thatcher et al. [82] suggested that commitment is an enduring and stable construct in short-term changes to service performance. Consistent with the results of previous studies, this study found that both affective and calculative commitments were strong determinants of consumers' brand loyalty and willingness to pay more in the context of coffee chain retailers. Furthermore, our findings confirm that affective and calculative commitments play a significant role in evoking positive emotions such as pleasure, happiness, and excitement. In particular, this study indicates that both affective and calculative commitment significantly affect consumers' brand loyalty and willingness to pay more in two ways: by indirectly affecting them through emotional responses and by directly influencing them. However, while affective commitment negatively influence negative emotion, calculative commitment positively affect it. In line with our results, Jone et al. [20] pointed out that calculative commitment could produce harmful outcomes in the form of negative emotions about. Therefore, our study confirms the dual role of calculative commitment in forming brand loyalty and willingness to pay more in the context of coffee chain retailers.

This study has explored the key determinants of affective and calculative commitments in the coffee chain retailer environment. Service quality, quality of physical environment, and price fairness-but not coffee quality-explained a significant portion of the variance of affective commitment. One possible explanation of the result for service quality is that consumers with higher perceptions of a coffee chain shop's service quality are more likely to remain loyal and have a higher willingness to pay more to their current coffee chain shop through attractive commitment. 
Concerning physical environment quality, consumers who believe that the current coffee chain retailer provides a high-quality physical environment will develop a high level of attractive commitment to it. Importantly, price fairness plays a prominent role in generating both affective and calculative commitments. This implies that the stronger a consumer's perception of the price fairness of a certain coffee chain retailer, the more likely the consumer is to stay with it instead of switching to an alternative. Consistent with our results, Yang et al. [66] reported that price fairness acted as a vital driver in elucidating both dedication- and constraint-based mechanisms and indicated that price fairness was the dominant factor and served as a key antecedent to the formation of both affective and calculative commitments in the context of coffee chain retailers. Moreover, contrary to service marketing and hospital management studies indicating that coffee quality serves as a key antecedent of the formation of positive attitudes toward coffee chains, our results showed that neither affective nor calculative commitment is significantly associated with coffee quality. Although coffee quality seems to be accepted as a fundamental and essential attribute of coffee chain retailers, it does not seem to matter to customers, perhaps because consumers regard coffee chain retailers as venues for meeting their need for social interaction, beyond just drinking a cup of coffee. The insignificance of coffee quality may also stem from the difficulty of differentiating between coffee qualities, such as aroma and freshness. The effects of service quality and quality of physical environment on calculative commitment were insignificant. Although consumers rationally evaluate service experiences based on functional, mechanical, and humane cues, the mechanical cues of coffee chains do not significantly affect consumer commitment in this context due to the homogeneous and undifferentiated physical environments across coffee chain brands.

Overall, previous service management and marketing works on finding vital factors of consumers' brand loyalty and willingness to pay more have missed the coffee chain settings. The findings of this study might fill the gap of the coffee industry that heavily depend on human feelings and experience research and practical areas, and thus help the coffee chain retailers to develop a sustainability strategy establishing brand loyalty and increasing wiliness to pay for the service.

\subsection{Implications for Research}

This study presents several theoretical implications. First, one major contribution of this study is that it simultaneously investigated two consumer loyalty behavior components-brand royalty and willingness to pay more-by synthesizing emotions and the dedication-constraint model in the context of coffee chain shops. Both consumer emotions and dedication-constraint-based factors play important roles in the development of loyalty behaviors. However, most studies have focused on loyalty behaviors such as repurchase intentions, WOM, and recommendation. Furthermore, few studies have combined emotions and the dedication-constraint model. Our findings indicate that both emotions and the dedication-constraint model are essential predictors of loyalty behaviors in the context of coffee chain shops. By demonstrating that constructs originating from prior emotions and the dedication-constraint model are critical determinants of loyalty behaviors, this study provides preliminary evidence that these two research disciplines could complement each other in developing a synergistic framework to investigate consumers' loyalty behaviors. Consumers' positive (but not negative) emotion and dedication-constraint mechanisms play important roles in forming brand loyalty and inducing a willingness to pay more. However, consumers' negative emotion negatively affects brand loyalty.

Second, this study clarifies the effects of emotional responses on loyalty behaviors in the context of coffee chain shops. Due to the complexity of the ambivalent view of emotions, most studies have focused on positive emotions. Contrariwise, this study fully captures the exact roles of both positive and negative consumer emotion in the development of loyalty behaviors in the context of coffee chain shops. According to the affective event theory, affective responses determine affect-driven behaviors such as recommendation and positive WOM [83]. Consistent with this theory, our findings indicate that both forms of emotional responses are significant factors of developing brand loyalty and 
willingness to pay more in the context of coffee chain shops. Furthermore, our findings show that positive emotional responses have a stronger effect on loyalty behaviors than negative emotion have. Contrary to previous findings, this study has shown that consumers' positive emotion felt while using coffee chain services are a stronger antecedent of consumers' loyalty behavior processes than their negative emotion is.

Third, this study investigated the roles of affective and calculative commitments in loyalty behaviors in the context of coffee chain shops. Both affective and calculative commitments were found to have significant effects on loyalty behaviors. Affective commitment is the strongest driver of positive emotional responses but is negatively related to negative emotional responses. Contrariwise, calculative commitment has significant positive effects on positive emotion and loyalty behaviors and is also positively associated with negative emotion. Although some studies on calculative commitment found direct and positive effects on loyalty, Sharma, Young, and Wilkinson [84] pointed out the dual role of calculative commitment in decisions to stay with a current provider, as perceived lack of alternative options derived from negative calculative commitment, while positive calculative commitment derived from a rational calculation of the benefits of staying with a current service provider [85]. We found that calculative commitment has both positive and negative consequences in the coffee chain environment.

Fourth, this study provides an in-depth understanding of the key antecedents of affective and calculative commitments in the coffee chain environment. We posited coffee quality, service quality, quality of physical environments, and price fairness as vital enablers of affective and calculative commitments. The analysis results confirm the salience of these four enablers in the creation of affective and calculative commitment. Both service quality and physical environment quality have significant effects on affective and calculative commitment. Price fairness has significant effects on both affective and calculative commitment as well.

\subsection{Implications for Practice}

First, our study shows that practitioners should focus on consumers' emotional responses to enhance customers' loyalty behaviors. Service practitioners should maximize customers' positive emotional experiences while minimizing negative ones. Specifically, this study confirmed the damaging effect of negative emotion on retailers' relationship with their existing consumers. Because deterrence emotions can evoke negative outcomes such as spreading negative WOM and complaint behaviors, service managers should try to reduce the formation of negative emotions by detecting and removing any service failures or problems in their service and offering prompt and timely assistance when problems occur. Service-recovery efforts can rebuild relationships with customers after negative experiences, eventually leading to long-term and enduring profitability. Therefore, service managers should concentrate on providing satisfying and favorable and delightful experiences to customers.

Second, our empirical investigation of the role of affective commitment and its antecedents in coffee chain retailing offers several practical implications for service practitioners and managers wishing to improve customers' loyalty behaviors. Service practitioners should focus on developing high levels of affective commitment to build and maintain long-term relationships with consumers. They should strive to offer higher levels of service quality, physical environment quality, and price fairness to leverage the dedication-based mechanism. High customer perceptions of service quality, quality of physical environment, and price fairness in a service provider enhance the formation of affective commitment, which in turn evokes positive emotions and ultimately enhances customers' brand loyalty and willingness to pay more. To enhance favorable user perceptions and facilitate relationship management, service managers should offer high-quality services in terms of customer service, the physical environment, and perceived price fairness. Our results suggest that price fairness is the strongest factor in affective commitment.

Finally, understanding the role of calculative commitment may provide insights for service managers to develop operations and marketing strategies. Service managers should carefully manage 
calculative commitment while forming their relationships with consumers. Although most studies have concentrated on the positive effect of the constraint-based mechanism on loyalty behaviors, it can both evoke negative and positive emotional responses simultaneously. Our findings confirmed the significant roles of calculative commitment in generating negative and positive emotional responses. As calculative commitment is counterproductive, increasing consumers' perceptions of calculative commitment can negatively affect relationships with consumers. Since consumers may perceive a negative calculative commitment due to a lack of alternative options, service practitioners should focus on promoting some benefits of staying with the current service provider.

\subsection{Limitations and Future Works}

Although our findings identified significant factors of brand loyalty and willingness to pay more in the context of coffee chain, the study has several limitations. First, although the coffee chain market has gained popularity across the world, we did not consider the effect of cultural attributes on consumers' decision-making processes in the context of coffee chain. Additional surveys should be conducted in other countries to identify the exact role of cultural factors in customers' brand loyalty and willingness to pay more. The results will be particularly useful for understanding the cultural difference of consumers' decision-making processes. Thus, we can apply these results into developing service operations and marketing campaigns. Second, this study used a cross-sectional survey method and investigated the determinants of customers' behaviors at a static point. To provide more insight for service managers, it will be valuable to capture dynamic effects of emotional responses, affective commitment, and calculative commitment on customers' loyalty behaviors. Future research can use a longitudinal survey method to track the dynamic effects of emotional responses, affective commitment, and calculative commitment on customers' brand loyalty and willingness to pay more in the context of coffee chain.

Author Contributions: Conceptualization: D.K.; Formal Analysis: B.S. and D.K.; Writing-Original draft preparation: D.K.; Writing-Reviewing and editing: B.K.; Funding Acquisition: D.K.

Funding: This work was supported by a research grant from Seoul Women's University (2018).

Conflicts of Interest: The authors declare no conflicts of interest.

\section{Appendix A. List of Model Constructs and Items}

Brand loyalty is derived from Yoo and Donthu [86].

BRL1: This brand is always my first choice.

BRL2: I consider myself to be loyal to this brand.

BRL3: I would recommend this brand to my friends or others.

BRL4: I encourage my friends or others to buy this brand.

Willingness to pay more is derived from Chaudhuri and Holbrook [52].

WPM1: Buying this brand seems smart to me even if they cost more.

WPM2: I'm ready to pay a higher price for this brand.

WPM3: I'd still buy this brand if other brands reduced their prices.

Positive emotion is derived from Jones et al. [20].

PEM1: Excited.

PEM2: Thrilled.

PEM3: Delighted.

Negative emotion is derived from Jones et al. [20].

NEM1: Frustrated.

NEM2: Angry.

NEM3: Irritated. 
Affective commitment is derived from Jones et al. [20].

ACO1: I like this brand.

ACO2: I buy this brand because I really like it.

ACO3: I am a customer of this brand because I feel a strong sense of attachment to it.

Calculative commitment is derived from Jones et al. [20].

CCO1: I feel somewhat locked into buying this brand.

CCO2: I feel sort of stuck with this brand.

CCO3: Some aspects of my life would be affected if I stop buying this brand now.

CCO4: To stop buying this brand would require considerable personal sacrifice.

Coffee quality is derived from $\mathrm{Chen}$ and $\mathrm{Hu}$ [24].

COQ1: The quality of coffee at this brand is consistently high during each visit.

COQ2: This brand offers coffee with excellent freshness.

COQ3: This brand offers coffee with risk flavor.

COQ4: This brand at this brand offers coffee with appropriate temperature.

Service quality is derived from Ryu et al. [68].

SEQ1: Employees at this brand serve me beverages exactly as I ordered it.

SEQ2: Employees at this brand provide prompt and quick service.

SEQ3: Employees at this brand are always willing to help me.

SEQ4: Employees at this brand make me feel comfortable in dealing with them.

Quality of physical environment is derived from Ryu et al. [68].

QPE1: The stores at this brand have a visually attractive interior design and decor.

QPE2: The stores at this brand have music and illumination appropriate for its atmosphere.

QPE3: The stores and equipment are thoroughly clean.

QPE4: Employees are neat and well dressed.

Price fairness is derived from Ryu and Lee [70].

PFA1: The coffee prices at this brand are fair.

PFA2: The beverage prices at this brand are fair.

PFA3: The price charged by this brand is appropriate.

PFA4: The price charged by this brand is rational.

\section{References}

1. Hu, H.; Parsa, H.; Self, J. The dynamics of green restaurant patronage. Cornell Hosp. Q. 2010, 51, 344-362. [CrossRef]

2. Jang, Y.J.; Kim, W.G.; Lee, H.Y. Coffee shop consumers' emotional attachment and loyalty to green stores: The moderating role of green consciousness. Int. J. Hosp. Manag. 2015, 44, 146-156. [CrossRef]

3. Laroche, M.; Bergeron, J.; Barbaro-Forleo, G. Targeting consumers who are willing to pay more for environmentally friendly products. J. Consum. Mark. 2001, 18, 503-520. [CrossRef]

4. Kim, B. The role of dedication-based and constraint-based mechanisms in consumers' sustainable outcomes in the coffee chain industry. Sustainability 2018, 10, 2636. [CrossRef]

5. Johnson, M.D.; Herrmann, A.; Huber, F. The evolution of loyalty intentions. J. Mark. 2006, 70, 122-132. [CrossRef]

6. Homburg, C.; Koschate, N.; Hoyer, W.D. Do satisfied customers really pay more? A study of the relationship between customer satisfaction and willingness to pay. J. Mark. 2005, 69, 84-96. [CrossRef]

7. Thomson, M.; Macinnis, D.J. The ties that bind: Measuring the strength of consumers' emotional attachments to brands. J. Consum. Psychol. 2005, 15, 77-91. [CrossRef]

8. Srinivasan, S.S.; Anderson, R.; Ponnavolu, K. Customer loyalty in e-commerce: An exploration of its antecedents and consequences. J. Retail. 2002, 78, 41-50. [CrossRef] 
9. Batra, R.; Ahuvia, A.; Bagozi, R. Brand Love. J. Mark. 2012, 76, 1-16. [CrossRef]

10. Bigné, J.E.; Andreu, L.; Gnoth, J. The theme park experience: An analysis of pleasure, arousal and satisfaction. Tour. Mark. 2005, 26, 833-844. [CrossRef]

11. Barsky, J.; Nash, L. Evoking emotion: Affective keys to hotel loyalty. Cornell Hotel. Restaur. Adm. Q. 2002, 43, 39-46. [CrossRef]

12. Yu, Y.T.; Dean, A. The contribution of emotional satisfaction to consumer loyalty. Int. J. Serv. Ind. 2001, 12, 234-250. [CrossRef]

13. Meyer, J.P.; Herscovitch, L. Commitment in the workplace: Toward a general model. Hum. Resour. Manag. Rev. 2001, 11, 299-326. [CrossRef]

14. Bendapudi, N.; Berry, L.L. Customers' motivations for maintaining relationships with service providers. J. Retail. 1997, 73, 15-37. [CrossRef]

15. Kim, B.; Min, J. The distinct roles of dedication-based and constraint-based mechanisms in social networking sites. Internet Res. 2015, 25, 30-51. [CrossRef]

16. Zeithaml, V.A.; Berry, L.L.; Parasuraman, A. The behavioral consequences of service quality. J. Mark. 1996, 60, 31-46. [CrossRef]

17. Lee, Y.C. m-Brand loyalty and post-adoption variations for the mobile data services: Gender differences Author links open overlay panel. Comput. Hum. Behav. 2011, 27, 2364-2371. [CrossRef]

18. Bloemer, J.; Odekerken-Schröder, G. The psychological antecedents of enduring customer relationships: An empirical study in a bank setting. J. Relatsh. 2007, 6, 21-43. [CrossRef]

19. Kaur, H.; Soch, H. Validating antecedents of customer loyalty for Indian cell phone users. Vikalpa 2012, 37, $47-61$.

20. Jones, M.A.; Reynolds, K.E.; Mothersbaugh, D.L.; Beatty, M.S. The positive and negative effects of switching costs on relational outcomes. J. Serv. Res. 2007, 9, 335-355. [CrossRef]

21. Han, H.; Ryu, K. The roles of the physical environment, price perception, and customer satisfaction in determining customer loyalty in the restaurant industry. J. Hosp. Tour. Res. 2009, 33, 487-510. [CrossRef]

22. Han, H.; Ryu, K. Key factors driving customers' word-of-mouth intentions in full-service restaurants: The moderating role of switching costs. Cornell Hosp. Q. 2012, 28, 1-14. [CrossRef]

23. Alan, A.K.; Kabadayi, E.T.; Yilmaz, C. Cognitive and affective constituents of the consumption experience in retail service settings: Effects on store loyalty. Serv. Bus. 2016, 10, 715-735. [CrossRef]

24. Chen, P.T.; Hu, H.H. How determinant attributes of service quality influence customer perceived value. Int. J. Contemp. Hosp. Manag. 2010, 22, 535-551. [CrossRef]

25. Havlena, W.J.; Holbrook, M.B. The varieties of consumption experience: Comparing two typologies of emotion in consumer behavior. J. Consum. Res. 1986, 13, 394-404. [CrossRef]

26. Westbrook, R.A.; Oliver, R.L. The dimensionality of consumption emotion patterns and consumer satisfaction. J. Consum. Res. 1991, 18, 84-91. [CrossRef]

27. Gardner, M.P. Mood states and consumer behavior: A critical review. J. Consum. Res. 1985, 12, $281-300$. [CrossRef]

28. Han, H.; Back, K.; Barrett, B. Influencing factors on restaurant customers' revisit intention: The roles of emotions and switching barriers. Int. J. Hosp. Manag. 2009, 28, 563-572. [CrossRef]

29. Han, H.; Back, K. Assessing guest emotional experiences influencing customer satisfaction in the lodging industry. J. Travel Tour. Mark. 2007, 23, 43-56. [CrossRef]

30. Ladhari, R. Service quality, emotional satisfaction, and behavioral intentions: A study in the hotel industry. Manag. Serv. Qual. 2009, 19, 308-331. [CrossRef]

31. Lee, Y.K.; Lee, C.K.; Lee, S.K.; Babin, B.J. Festivalscapes and patrons' emotions, satisfaction, and loyalty. J. Bus. Res. 2008, 61, 56-64. [CrossRef]

32. Jung, H.S.; Yoon, H.H. The effects of nonverbal communication of employees in the family restaurant upon customers' emotional responses and customer satisfaction. Int. J. Hosp. Manag. 2011, 30, 542-550. [CrossRef]

33. Beaudry, A.; Pinsonneault, A. The other side of acceptance: Studying the direct and indirect effects of emotions on information technology use. MIS Q. 2010, 34, 689-710. [CrossRef]

34. Wakefield, R. The influence of user affect in online information disclosure. J. Strateg. Inf. Syst. 2013, 22, 157-174. [CrossRef]

35. Laros, F.J.M.; Steenkamp, J.B.E.M. Emotions in consumer behavior: A hierarchical approach. J. Bus. Res. 2005, 58, 1437-1445. [CrossRef] 
36. Phillips, D.M.; Baumgartner, H. The role of consumption emotions in the satisfaction response. J. Consum. Psychol. 2002, 12, 243-252. [CrossRef]

37. Cacioppo, J.T.; Gardner, W.L.; Berntson, G.G. Beyond bipolar conceptualizations and measures: The case of attitudes and evaluative space. Pers. Soc. Psychol. Rev. 1997, 1, 3-25. [CrossRef] [PubMed]

38. Penz, E.; Hogg, M.K. The role of mixed emotions in consumer behaviour: Investigating ambivalence in consumers' experiences of approach-avoidance conflicts in online and offline settings. Eur. J. Mark. 2011, 45, 104-132. [CrossRef]

39. Pappas, I.O.; Kourouthanassis, P.E.; Giannakos, M.N.; Chrissikopoulos, V. Shiny happy people buying: The role of emotions on personalized e-shopping. Electron. Mark. 2014, 24, 193-206. [CrossRef]

40. Kuo, Y.F.; Wu, C.M. Satisfaction and post-purchase intentions with service recovery of online shopping websites: Perspectives on perceived justice and emotions. Int. J. Inf. Manag. 2012, 32, 127-138. [CrossRef]

41. Garbarino, E.; Johnson, M.S. The different roles of satisfaction, trust, and commitment in customer relationships. J. Mark. 1999, 63, 70-87. [CrossRef]

42. Zhou, Z.; Fang, Y.; Vogel, D.R.; Jin, X.L.; Zhang, X.I. Attracted to or locked in? Predicting continuance intention in social virtual world services. J. Manag. Inf. Syst. 2012, 29, 273-305. [CrossRef]

43. Lin, T.C.; Huang, S.L.; Hsu, C.J. A dual-factor model of loyalty to IT product-The case of smartphones. Int. J. Inf. Manag. 2015, 35, 215-228. [CrossRef]

44. Baloglu, S.; Zhong, Y.Y.; Tanfor, S. Casino loyalty: The influence of loyalty program, switching costs, and trust. J. Hosp. Tour. Res. 2014, 41, 846-868. [CrossRef]

45. Gounaris, S.P. Trust and commitment influences on customer retention: Insights from business-to-business services. J. Bus. Res. 2005, 58, 126-140. [CrossRef]

46. Chou, S.W.; Chiang, C.H. Understanding the formation of software-as-a-service (SaaS) satisfaction from the perspective of service quality. Decis. Support Syst. 2013, 56, 148-155. [CrossRef]

47. Lu, T.; Tu, R.; Jen, W. The role of service value and switching barriers in an integrated model of behavioural intentions. Total Qual. Manag. 2011, 22, 1071-1089. [CrossRef]

48. Kim, B. Understanding key antecedents of user loyalty toward mobile messenger applications: An integrative view of emotions and the dedication-constraint model. Int. J. Hum. Comput. Interact. 2017, 33, 984-1000. [CrossRef]

49. Tanford, S.; Raab, C.; Kim, Y.S. Determinants of customer loyalty and purchasing behavior for full-service and limited-service hotels, Int. J. Hosp. Manag. 2012, 31, 319-328. [CrossRef]

50. Rust, R.T.; Oliver, R.L. Should we delight the customer? J. Acad. Mark. Sci. 2000, 28, 86-94. [CrossRef]

51. Chea, S.; Luo, M.M. Post-adoption behaviors of e-service customers: The interplay of cognition and emotion. Int. J. Electron. Commer. 2008, 12, 29-56. [CrossRef]

52. Chaudhuri, A.; Holbrook, M.B. The chain of effects from brand trust and brand affect to brand performance: The role of brand loyalty. J. Mark. 2001, 65, 81-93. [CrossRef]

53. Strahilevitz, M. The effect of product type and donation magnitude on willingness to pay more for a charity-linked brand. J. Consum. Psychol. 1999, 8, 215-241. [CrossRef]

54. Parasuraman, A.; Zeithaml, V.A.; Berry, L.L. SERVQUAL: A multiple-item scale for measuring consumer perceptions of service quality. J. Retail. 1988, 64, 12-40.

55. Delgado-Ballester, E.; Munuera-Alemán, J.L. Brand trust in the context of consumer loyalty. Eur. J. Mark. 2001, 35, 1238-1258. [CrossRef]

56. Verhoef, P.C. Understanding the effect of customer relationship management efforts on customer retention and customer share development. J. Mark. 2003, 67, 30-45. [CrossRef]

57. Zhou, T.; Lu, Y. Examining post-adoption usage of mobile services from a dual perspective of enablers and inhibitors. Int. J. Hum. Comput. Interact. 2012, 27, 1177-1191. [CrossRef]

58. Han, H.; Nguyen, H.N.; Song, H.; Chua, B.L.; Lee, S.; Kim, W.S. Drivers of brand loyalty in the chain coffee shop industry. Int. J. Hosp. Manag. 2018, 72, 86-97. [CrossRef]

59. Mathieu, J.; Zajac, D. A review and meta-analysis of the antecedents, correlates, and consequences of organizational commitment. Psychol. Bull. 1990, 108, 171-194. [CrossRef]

60. Gundlach, G.; Achrol, R.; Mentzer, J. The structure of commitment in exchange. J. Mark. 1995, 59, 72-92. [CrossRef]

61. Fullerton, G. When does commitment lead to loyalty? J. Serv. Res. 2003, 5, 333-344. [CrossRef] 
62. Gustafsson, A.; Johnson, M.D.; Roos, I. The effects of customer satisfaction, relationship commitment dimensions, and triggers on customer retention. J. Mark. 2005, 69, 210-218. [CrossRef]

63. Jaros, S.J.; Jermier, J.M.; Koehler, J.W.; Sincich, T. Effects of continuance, affective, and moral commitment on the withdrawal process: An evaluation of eight structural equation models. Acad. Manag. J. 1993, 36, 951-995.

64. Bansal, H.S.; Irving, P.G.; Taylor, S.F. A three-component model of customer commitment to service providers. J. Acad. Mark. Sci. 2004, 32, 234-250. [CrossRef]

65. Bilgihan, A.; Barreda, A.; Okumus, F.; Nusair, K. Consumer perception of knowledge-sharing in travel-related online social networks. Tour. Mark. 2016, 52, 287-296. [CrossRef]

66. Yang, J.Y.; Kim, T.H.; Kim, M.J. The effects of customer satisfaction based on user experience on commitment, loyalty and repeated use in franchise and chain coffee shops. Culin. Sci. Hosp. Res. 2013, 19, $206-224$. [CrossRef]

67. Deci, E.L.; Ryan, R.M. Intrinsic Motivation and Self-Determination in Human Behavior; Plenum: New York, NY, USA, 1985.

68. Ryu, K.; Lee, H.R.; Kim, W.G. The influence of the quality of the physical environment, food, and service on restaurant image, customer perceived value, customer satisfaction, and behavioral intentions. Int. J. Contemp. Hosp. Manag. 2012, 24, 200-223. [CrossRef]

69. Bitner, M.J. Servicescapes: The impact of physical surroundings on customers and employees. J. Mark. 1992, 56, 57-71. [CrossRef]

70. Ryu, K.; Lee, J.S. Examination of restaurant quality, relationship benefits, and customer reciprocity from the perspective of relationship marketing investments. J. Hosp. Tour. Res. 2017, 41, 66-92. [CrossRef]

71. Tumanan, M.A.R.; Lansangan, J.R.G. More than just a cuppa coffee: A multi-dimensional approach towards analyzing the factors that define place attachment. Int. J. Hosp. Manag. 2012, 31, 529-534. [CrossRef]

72. Dodds, W.B.; Monroe, K.B.; Grewal, D. Effects of price, brand, and store information on buyers' product evaluations. J. Mark. Res. 1991, 28, 307-319. [CrossRef]

73. Jacoby, J.; Olson, J.C. Consumer Response to Price: An Attitudinal, Information Processing Perspective. In Moving Ahead with Attitude Research; Wind, Y., Greenberg, M., Eds.; American Marketing Association: Chicago, IL, USA, 1997; pp. 73-86.

74. Oh, H. Price fairness and its asymmetric effects on overall price, quality, and value judgments: The case of an upscale hotel. Tour. Mark. 2003, 24, 387-399. [CrossRef]

75. Campbell, J.L. Why would corporations behave in socially responsible ways? An institutional theory of corporate social responsibility. Acad. Manag. Rev. 2007, 32, 946-967. [CrossRef]

76. Homburg, C.; Totzek, D.; Kramer, M. How price complexity takes its toll: The neglected role of a simplicity bias and fairness in price evaluations. J. Bus. Res. 2014, 67, 1114-1122. [CrossRef]

77. Urbany, J.E.; Madden, T.J.; Dickson, P.R. All's not fair in pricing: An initial look at the dual entitlement principle. Mark. Lett. 1989, 1, 17-25. [CrossRef]

78. Chin, W.W. The partial least squares approach to structural equation modeling. In Modern Methods for Business Research; Marcoulides, G.A., Ed.; Lawrence Erlbaum Associates: Mahway, NJ, USA, 1998; pp. 295-336.

79. Anderson, J.C.; Gerbing, D.W. Structural equation modeling in practice: A review and recommended two-step approach. Psychol. Bull. 1988, 103, 411-423. [CrossRef]

80. Fornell, C.; Larcker, D.F. Evaluating structural evaluation models with unobservable variables and measurement error. J. Mark. Res. 1981, 18, 39-50. [CrossRef]

81. Hair, J.; Anderson, R.; Tatham, R.B. Multivariate Data Analysis; Prentice Hall: Upper Saddle River, NJ, USA, 1998.

82. Thatcher, J.B.; Stepina, L.P.; Boyle, R.J. Turnover of information technology workers: Examining empirically the influence of attitudes, job characteristics, and external markets. J. Manag. Inf. Syst. 2002, 19, 231-261.

83. Weiss, H.M.; Cropanzano, R. Affective events theory: A theoretical discussion of the structure, causes and consequences of affective experiences at work. In Research in Organizational Behavior: An Annual Series of Analytical Essays and Critical Review; Staw, B.M., Cummings, L.L., Eds.; JAI Press: Greenwich, CT, USA, 1996; Volume 18, pp. 1-74.

84. Sharma, N.; Young, L.; Wilkinson, I. The commitment mix: Dimensions of commitment in international trading relationships in India. J. Int. Mark. 2006, 14, 64-91. [CrossRef] 
85. Čater, T.; Čater, B. Product and relationship quality influence on customer commitment and loyalty in B2B manufacturing relationships. Ind. Mark. Manag. 2010, 39, 1321-1333. [CrossRef]

86. Yoo, B.; Donthu, N. Developing and validating a multidimensional consumer-based brand equity scale. J. Bus. Res. 2001, 52, 1-14. [CrossRef] 